\title{
Influence Behavior Toward Consumer Buying Decisions in House Type 36. Lagan Pangka Pekanbaru
}

\author{
Azhari ${ }^{1}$ \\ ${ }^{1}$ Sekolah Tinggi Ilmu Ekonomi Bangkinang
}

\begin{abstract}
The purpose of this study was to determine whether the factor of cultural, social, personal and psychological Influential Home Buying Decision Against Type 36 PT. Lagan Pangka Pekanbaru. Data analysis technique using multiple linear regression analysis. The samples used were 58 respondents with accidental sampling technique. Data collection techniques by questionnaire. Based on the results of this study concluded that the factor of cultural, social, personal and psychological significantly influence the purchase decision Houses Type 36 PT. Lagan Pangka Pekanbaru. Test the correlation coefficient (R) independent variable on the dependent variable are very strong closeness of 0.951 and a contribution of independent variables on the dependent variable (R2) was $89,70 \%$
\end{abstract}

\author{
Keywords: \\ Factor Culture, Social, \\ Personal, Psychological \\ and Purchase Decision
}

\section{Pendahuluan}

Rumah sebagai kebutuhan dasar manusia, perwujudannya bervariasi menurut siapa penghuni atau pemiliknya. Berdasarkan hierarchy of need (Maslow, 1954), Kebutuhan akan rumah sebagai, Pertama; Physiological needs (kebutuhan akan makan dan minum), merupakan kebutuhan biologis yang hampir sama untuk setiap orang, yang juga merupakan kebuthan terpenting selain rumah, sandang, dan pangan juga termasuk dalam tahap ini. Kedua; Safety or security needs (kebutuhan akan keamanan),merupakan tempat berlindung bagi penghuni dari gangguan manusia dan lingkungan yang tidak diinginkan. Ketiga; Social or afiliation needs (kebutuhan berinteraksi), sebagai tempat untuk berinteraksi dengan keluarga dan teman. Keempat; Self actualiztion needs (kebutuhan akan ekspresi diri), rumah bukan hanya sebagai tempat tinggal, tetapi menjadi tempat untuk mengaktualisasikan diri. Mengingat tingginya kebutuhan masyarakat akan perumahan, maka pihak pengembang (Developer) PT. Pangka Lagan memamfaatkan peluang yang ada dengan menyediakan rumah type 36 beserta fasilitas dan keunggulan tersebut. Kondisi demikian tentunya menimbulkan persaingan sangat ketat dipasaran, karena setiap developer akan membangun perumahan sesuai standar perumahan layak sekaligus menawarkan keunggulan produknya kepada masyarakat.

PT. Pangka Lagan Pekanbaru merupakan salah satu pengembang perumahan menyediakan rumah type 36. Pemasaran perumahan pada umumnya memiliki atribut penawaran hampir sama. PT. Pangka Lagan Pekanbaru mencoba memberikan penawaran perumahan salah satunya diberi nama Perumahan Naila Asri Residence dimana perumahan ini memiliki keunggulanya itu harga terjangkau, desain bangunan menarik, lokasi strategis, dan fasilitas-fasilitas lengkap. Jenis rumah yang dibangun oleh PT. Pangka Lagan Pekanbaru type 36. Sejak awal beroperasi di Pekanbaru yakni tahun 2013 jumlah bangunan type 36 sudah dibangun sampai sekarang dapat dilihat pada Tabel 1.

Tabel 1. Target dan Realisasi Penjualan Rumah type 36 pada PT. Pangka Lagan Pekanbaru

\begin{tabular}{|c|c|c|}
\hline Tahun & Realisasi penjualan rumah (unit) & Persentase (\%) \\
\hline 2013 & 19 & 21,11 \\
\hline 2014 & 21 & 23,33 \\
\hline 2015 & 18 & 20,00 \\
\hline Jumlah & 58 & 21,48 \\
\hline
\end{tabular}


Tabel 1 diatas menunjukkan dengan jelas pencapaian realisasi penjualan rumah type 36 pada PT. Pangka Lagan Pekanbaru belum tercapai sesuai target yang diharapkan dan cenderung mengalami fluktuasi selama 3 tahun terakhir, yakni secara keseluruhan realisasi penjualan rumah belum tercapai dari target yang ditetapkan. Kondisi ini mempertanyakan pengaruh perilaku konsumen dalam mengambil keputusan terhadap pembelian rumah type 36 seperti faktor budaya, sosial, pribadi dan psikologis.

Berdasarkan permasalahan di atas bahwa perilaku konsumen sangat penting untuk ditingkatkan karena dapat mempengaruhi pencapaian keputusan pembelian, maka rumusan permasalahan dalam penelitian ini apakah ada pengaruh perilaku konsumen secara simultan dan parsial terhadap keputusan pembelian, dan variabel manakah yang paling dominan pengaruhnya terhadap kepuasan pasien. Tujuan penelitian ini untuk mengetahui pengaruh kualitas pelayanan secara simultan dan parsial terhadap keputusan pembelian, dan variabel yang paling dominan pengaruhnya.

\section{Perilaku Konsumen}

Menurut Assauri, (2010) perilaku konsumen/pembeli merupakan tindakan seseorang/individu langsung menyangkut pencapaian dan penggunaan produk (barang atau jasa) termasuk proses mendahului dan menentukan tindakan tersebut. Perilaku konsumen pada hakikatnya untuk memahami "Mengapa konsumen melakukan dan apa yang mereka lakukan". Schiffman dan Kanuk (2008) mengemukakan bahwa studi perilaku konsumen adalah suatu studi mengenai bagaimana seorang individu membuat keputusan untuk mengalokasikan sumber daya yang tersedia (waktu, uang, usaha, dan energi). Konsumen memiliki keragaman yang menarik untuk dipelajari karena ia meliputi seluruh individu dari berbagai usia, latar belakang budaya, pendidikan, dan keadaan sosial ekonomi lainnya. Oleh karena itu, sangatlah penting untuk mempelajari bagaimana konsumen berperilaku dan faktor-faktor apa saja yang mempengaruhi perilaku tersebut.

Definisikan perilaku konsumen menurut Kotler dan Keller (2008): Perilaku konsumen adalah studi bagaimana individu, kelompok dan organisasi memilih, membeli, menggunakan dan menempatkan barang, jasa, ide atau pengalaman untuk memuaskan keinginan dan kebutuhan mereka. Definisisi perilaku konsumen menurut Schiffman dan Kanuk (2008): Perilaku konsumen menggambarkan cara individu mengambil keputusan untuk memanfaatkan sumber daya mereka yang tersedia (waktu, uang-usaha) guna membeli barang-barang yang berhubungan dengan konsumsi. Dari dua pengertian tentang perilaku konsumen di atas dapat diperoleh dua hal yang penting, yaitu: (1) sebagai kegiatan fisik dan (2) sebagai proses pengambilan keputusan. Berdasarkan beberapa definisi yang telah disebutkan di atas dapat disimpulkan bahwa perilaku konsumen adalah semua kegiatan, tindakan, serta proses psikologis yang mendorong tindakan tersebut pada saat sebelum membeli, ketika membeli, menggunakan, menghabiskan produk dan jasa setelah melakukan hal-hal di atas atau kegiatan mengevaluasi.

Terdapat faktor-faktor utama mempengaruhi perilaku konsumen yaitu: 1) Faktor Budaya, Kebudayaan merupakan penentu keinginan dan perilaku yang paling mendasar untuk mendapatkan nilai, persepsi, preferensi dan perilaku dari lembaga-lembaga penting lainnya. Faktor kebudayaan memberikan pengaruh paling luas dan dalam pada tingkah laku konsumen; 2) Faktor sosial, Faktor sosial merupakan pembagian masyarakat yang relatif homogen dan permanen yang tersusun secara hierarkis dan yang anggotanya menganut nilai-nilai, minat, dan perilaku yang serupa. Faktor sosial ditentukan oleh satu faktor tunggal, seperti pendapatan, tetapi diukur sebagai kombinasi dari pekerjaan, pendapatan, pendidikan, kekayaan dan variabel lain. Dalam beberapa sistem sosial, anggota dari kelas yang berbeda memelihara peran tertentu dan tidak dapat mengubah posisi sosial mereka; 3) Faktor pribadi, Faktor pribadi didefenisikan sebagai karateristik psikologis seseorang yang berbeda dengan orang lain yang menyebabkan tanggapan yang relatif konsisten dan bertahan lama terhadap lingkungan. Keputusan membeli juga dipengaruhi oleh karateristik pribadi; 4)Faktor fsikologis, Faktor kejiwaan atau psikologis sebagai bagian dari pengaruh lingkungan dimana ia tinggal dan hidup pada waktu sekarang tanpa mengabaikan pengaruh dimasa lampau atau antisipasinya pada waktu yang akan datang pilihan barang yang dibeli seseorang lebih lanjut dipengaruhi faktor psikologis. (http;//anggiechorium.blogspot.co.id /2012/04/faktor-faktoryangmempengaruhi.html,28/9/2016)

Kekuatan mempengaruhi perilaku konsumen pilihan pembelian seseorang merupakan hasil suatu proses kompleks saling mempengaruhi dari faktor-faktor budaya, sosial, pribadi dan fsikologis. Banyak diantara faktor ini tidak dapat dipengaruhi oleh pemasar. Namun demikian, factor-faktor ini berguna dalam mengidentifikasi para pembeli mungkin memilikin minat paling besar terhadap suatu produk. Faktor-faktor lain mungkin dapat dipengaruhi pemasar dan memberi petunjuk pada pemasar yaitu Product (Produk), Price (Harga), Promotion (Promosi), Place (Tempat), Distribution (Distribusi). 


\section{Keputusan Pembelian}

Menurut Kotler (2002), keputusan pembelian adalah tindakan dari konsumen untuk mau membeli atau tidak terhadap produk. Dari berbagai faktor yang mempengaruhi konsumen dalam melakukan pembelian suatu produk atau jasa, biasanya konsumen selalu mempertimbangkan kualitas, harga dan produk sudah yang sudah dikenal oleh masyarakat Sebelum konsumen memutuskan untuk membeli, biasanya konsumen melalui beberapa tahap terlebih dahulu yaitu, 1) pengenalan masalah; 2) pencarian informasi; 3) evaluasi alternative; 4) keputusan membeli atau tidak; 5) perilaku pascapembelian. Pengertian lain tentang Keputusan pembelian menurut Schiffman dan Kanuk (2000) adalah "the selection of an option from two or alternative choice". Dapat diartikan, keputusan pembelian adalah suatu keputusan seseorang dimana dia memilih salah satu dari beberapa alternatif pilihan yang ada.

Berdasarkan definisi diatas disimpulkan bahwa keputusan pembelian adalah tindakan yang dilakukan konsumen untuk melakukan pembelian sebuah produk. Oleh karena itu, pengambilan keputusan pembelian konsumen merupakan suatu proses pemilihan salah satu dari beberapa alternatif penyelesaian masalah dengan tindak lanjut yang nyata. Setelah itu konsumen dapat melakukan evaluasi pilihan dan kemudian dapat menentukan sikap yang akan diambil selanjutnya. Menurut Swastha dan Handoko (2011) berpendapat bahwa lima peran individu dalam sebuah keputusan membeli, yaitu: Pengambilan inisiatif (initiator): individu yang mempunyai inisiatif pembelian barang tertentu atau yang mempunyai kebutuhan atau keinginan tetapi tidak mempunyai wewenang untuk melakukan sendiri. Orang yang mempengaruhi (influencer): individu yang mempengaruhi keputusan untuk membeli baik secara sengaja maupun tidak sengaja.

Pembuat keputusan (decider): individu yang memutuskan apakah akan membeli atau tidak, apa yang akan dibeli, bagaimana membelinya, kapan dan dimana membelinya. Pembeli (buyer): individu yang melakukan pembelian yang sebenarnya. Pemakai (user): individu yang menikmati atau memakai produk atau jasa yang dibeli. Sebuah perusahaan perlu mengenai peranan tersebut karena semua peranan mengandung implikasi guna merancang produk, menentukan pesan dan mengalokasikan biaya anggaran promosi serta membuat program pemasaran yang sesuai dengan pembeli.

Keputusan pembeli suatu produk dilakukan oleh seseorang konsumen pada dasarnya tidaklah sama dalam artian adalah type tertentu menjadi ciri konsumen dalam pembelian. Ada empat tipe pembelian dilakukan konsumen, meliputi (Thamrin \& Tantri, 2012) Perilaku pembelian kompleks, Konsumen mempunyai perilaku pembelian kompleks jika mereka sangat terlibat dalam suat pembelian dan menyadari adanya perbedaan signifikan antara beberapa merek. Pembelian ini akan melalui suatu proses belajar pertama ditandai dengan mengembang keyakinan mengenai produk tersebut, kemudian sikap dan lalu membuat pilihan pembelian dengan bijaksana; 2) Perilaku pembelian mengurangi ketidaksesuaian (disonansi), Kadang-kadang konsumen sangat terlibat dalam suatu pembelian, tetapi tidak melihat banyak perbedaan dalam merek. Keterlibatan tinggi ini sekali lagi berdasarkan kenyataan bahwa pembelian tersebut bersifat mahal, jarang dilakukan, dan beresiko.

Dalam kasus ini, pembeli akan berkeliling untuk mempelajari apa saja tersedia, tetapi akan melakukan pembelian dengan cukup cepat karena perbedaan merek tidak nyata. Setelah pembelian, konsumen tersebut mungkin mengalami ketidaksesuaian disebabkan oleh adanya karateristik tertentu dari pembelian produk tersebut dirasakan kurang memuaskan atau mendengar hal-hal menyenangkan mengenai produk sejenis lainnya; 3) Perilaku pembelian menurut kebiasaan, Banyak produk dibeli dengan keterlibatan konsumen rendah dan tidak ada perbedaan merek signifikan. Konsumen mempunyai keterlibatan rendah dengan kebanyakan produk murah dan sering dibeli. Perilaku konsumen dalam pembelian ini, tidak melui tahap-tahap keyakinan, sikap, atau perilaku normal; 4) Perilaku pembelian mencari variasi, Beberapa situasi pembelian ditandai dengan keterlibatan konsumen rendah, tetapi perbedaan merek signifikan. Dalam hal ini, konsumen kerap kali melakukan peralihan merek (brand switching).

\section{Metode Penelitian}

Populasi penelitian ini adalah seluruh konsumen perumahan PT. Pangka Lagan Pekanbaru khusus type 36 yang berjumlah 58 orang. Pengambilan sampel dilakukan secara metode sensus atau sampel jenuh, artinya teknik penentuan sampel bila semua anggota populasi digunakan sebagai sampel, yaitu sebanyak 58 orang. Jenis dan sumber data utama yang digunakan dalam penelitian ini adalah data primer, yaitu data yang diperoleh dari jawaban responden melalui kuesioner.Alat analisis data yang digunakan dalam penelitian ini adalah Regresi Linear Bergandadengan rumus $Y=\alpha+\beta_{1} X_{1}+\beta_{2} X_{2}+\beta_{3} X_{3}+\beta_{4} X_{4}+\varepsilon$. 


\section{Hasil dan Pembahasan}

Berdasarkan Tabel 4 bahwa kualitas pelayanan secara bersama-sama (simultan) berpengaruh signifikan terhadap keputusan pembelian rumah type 36 pada PT. Pangka Lagan Pekanbaru. Berikut pembahasan hasil penelitian dari variable factor budaya, social, pribadi dan psikologis. Faktor budaya memberikan pengaruh paling luas dan mendalam pada tingkah laku konsumen. Pemasaran harus mengetahui peran yang dimainkan oleh budaya-budaya, sub-budaya, dan kelas sosial. Budaya mengacu pada gagasan, simbol-simbol yang memiliki makna untuk berkomunikasi, nilai, melakukan penafsiran dan evaluasi sebagai anggota masyarakat. Budaya dapat dilihat dari kepercayaan, pandangan dan kebiasaan konsumen terhadap suatu produk. Semakin tinggi kepercayaan terhadap produk, maka semakin tinggi keputusan konsumen untuk melakukan pembelian.

Berdasarkan uji secara individu (masing-masing) pada Tabel 5 bahwa Faktor sosial berpengaruh signifikan terhadap keputusan pembelian rumah type 36 pada PT. Pangka Lagan Pekanbaru. Hal ini dikarenakan Tingkah laku konsumen yg dipengaruhi oleh faktor-faktor sosial seperti kelompok referensi, keluarga, serta peran dan status sosial konsumen. Kelompok referensi memiliki pengaruh langsung (tatap muka) atau pengaruh tidak langsung pada sikap dan perilaku seseorang. Kelas sosial kadang-kadang berupa suatu system kasta dimana anggota dari kasta yang berbeda untuk peranan-peranan tertentu dapat mengubah keanggotaan kasta mereka, termasuk dalam pembelian suatu produk. Faktor sosial dapat dilihat dari hubungan dengan teman, keluarga dan orang tua dalam mempengaruhi keputusan pembelian. Semakin tinggi hubungan dengan teman, keluarga dan orang tua, maka semakin tinggi keputusan konsumen untuk melakukan pembelian.

Berdasarkan uji secara individu (masing-masing) pada Tabel 5 bahwa Faktor pribadi berpengaruh signifikan terhadap keputusan pembelian rumah type 36 pada PT. Pangka Lagan Pekanbaru. Hal ini dikarenakan Perilaku seseorang dalam membeli sesuatu juga dipengaruhi oleh faktor-faktor kepribadian dari konsumen yang bersangkutan. Faktor pribadi menggabungkan antara tatanan psikologis dan pengaruh lingkungan. Termasuk watak, dasar seseorang, terutama karakteristik dominan mereka. Meskipun kepribadian adalah salah satu konsep yang berguna dalam mempelajari perilaku konsumen, beberapa pemasar percaya bahwa kepribadian mempengaruhi jenis-jenis dan merek-merek produk yang dibeli. Kepribadian seseorang terbentuk disebabkan oleh bermacam-macam indikator, seperti pekerjaan orang tua, keadaan ekonomi dan gaya hidup. Semakin tinggi jabatan orang tua dalam bekerja, mapan dari segi ekonomi dan gaya hidup yang semakin meningkat, maka semakin tinggi keputusannya untuk membeli suatu produk.

Berdasarkan uji secara individu (masing-masing) pada Tabel 5 bahwa Faktor Psikologis berpengaruh signifikan terhadap keputusan pembelian rumah type 36 pada PT. Pangka Lagan Pekanbaru. Hal ini karena Pilihan pembelian seseorang dipengaruhi oleh empat faktor psikologis utama, yaitu motivasi, persepsi, pengetahuan, keyakinan dan sikap. Motivasi seseorang memiliki beberapa kebutuhan pada suatu waktu, bisa biogenik, yaitu muncul dari ketegangan fisiologis, seperti lapar, dahaga, kenyamanan, kebutuhan psikogenik, yaitu muncul dari ketegangan psikologis, seperti kebutuhan untuk diakui, harga diri dan merasa terhina di lingkungan masyarakat. Semakin tinggi motivasi, persepsi, pengetahuan, keyakinan dan sikap seseorang terhadap suatu produk, maka semakin tinggi keputusan konsumen untuk melakukan pembelian.

Dari empat variabel tersebut yang paling dominan dan menonjol diantara variabel yang lainnya adalah Faktor pribadi terbukti dari hasil ujit didapat t hitung sebesar 3,454 dan signifikansi sebesar 0,001 yang mana lebih besar t hitungnya dari variabel lainnya.uji simultan (uji F) terlihat hasil perhitungan diperoleh nilai signifikansi sebesar 0,000. Oleh karena itu signifikansi $F$ hitung lebih kecil dari alpa $(\alpha)$ yaitu signifikan sebesar $0,000<0,05$. Dengan demikian hipotesis dalam penelitian ini dapat diterima.

Jadi, dari penjelasan secara teori dan hasil dari penelitian dan pengolahan data SPSS versi 22, dapat disimpulkan bahwa benar faktor budaya, sosial, pribadi dan psikologis berpengaruh signifikan terhadap keputusan pembelian rumah type 36 pada PT. Pangka Lagan Pekanbaru.

\section{Simpulan}

Secara simultan faktor budaya, sosial, pribadi dan psikologis pengaruh signifikan terhadap keputusan pembelian rumah pada PT. Pangka Lagan pekanbaru. Secara parsial faktor budaya, sosial, pribadi dan psikologis pengaruh signifikan terhadap keputusan pembelian rumah pada PT. Pangka Lagan pekanbaru. Variabel yang paling dominan pengaruh nya terhadap keputusan pembelian rumah type 36 pada PT. Pangka Lagan Pekanbaru yaitu faktor pribadi. Hubungan antara variabel bebas terhadap variabel terikat sangat erat. 


\section{Daftar Pustaka}

Abdullah, Thamrin \& Francis Tantri. (2012). Manajement Pemasaran. Edisi Satu. Cetakan ke - 3. Jakarta : Pangka Lagan Pers

Abdullah, Thamrin dan Francis Tantri. (2012). Manajemen Pemasaran. Depok: PT Raja Grafindo Persada

Alma, Bukhari, (2013).Manajement Pemasaran \& Pemasaran Jasa. Jakarta

Assauri, Sofjan, SE. MBA. (2010).Manajement Pemasaran, Dasar, Konsep dan Strategi. Jakarta.

Basu Swastha, Hani Handoko. (2011). Manajemen Pemasaran-Analisis Perilaku. Konsumen. Yogyakarta : BPFE.

Charles W. Lamb, Joseph F. Hair, Carl Mcdaniel. (2001). Pemasaran. Edisi. Pertama, Salemba Empat, Jakarta.

Dantes, Nyoman Prof Dr. (2012). Metode Penelitian. Yogyakarta. CV Andi Offset

Ginting, Hartimbul F. Nembah. (2011). Manajemen Pemasaran. Bandung : CV Yrama Widya

Herlambang. (2014). Basic Marketing. Cetakan pertama. Yogjakarta

Hurriyati, Ratih. (2005). Bauran Pemasaran dan Loyalitas Konsumen, Alfabeta.

Jogiyanto. (2012). Metodologi Penelitian Bisnis. Yogyakarta: KPYE IKAPI

Kevin Lane Keller. (2008). Manajemen Pemasaran, Jilid 1, Penerbit Erlangga. Jakarta.

Kirom, Bahrul. (2010). Mengukur Kinerja Pelayanan dan Kepuasan Konsumen.

Kotler, Philip. (2002). Manajemen Pemasaran, Jilid 1, Edisi Milenium, Jakarta, Prehallindo.

Schiffman, Leon G dan Kanuk. (2008). Consumer Behavior, Prentice Hall Internasional

Sugiyono. (2001). Metode Penelitian Bisnis, Cetakan Ketiga Penerbit: Alfabeta, Bandung

Sutisna. (2003). Perilaku Konsumen dan Komunikasi Pemasaran. PT. Remaja Rosdakarya, Bandung.

Suwarman. (2014). Perilaku Konsumen Teori Penerapannya dalam Pemasaran. Edisi ke -2 .Bogor

Ujang Suwarman. (2004). Perilaku Konsumen Teori dan Penerapannya dalam Pemasaran, Penerbit: PT Ghalia Indonesia, Bogor.

Uma Sekaran. (2006) Metodologi Penelitian untuk Bisnis, Edisi 4, Buku 1, Jakarta 